International Journal of Biological Sciences

ISSN 1449-2288 www.biolsci.org 2007 3(4):257-262

Research Paper

(c) Ivyspring International Publisher. All rights reserved

\title{
Enrichment of coenzyme Q10 in plasma and blood cells: deiense against oxidative damage
}

\author{
Petra Niklowitz ${ }^{1}$, Anka Sonnenschein ${ }^{2}$, Bernd Janetzky ${ }^{2}$, Werner Andler ${ }^{1}$, Thomas Menke ${ }^{1}$ \\ 1. Vestische Kinderklinik Datteln, University Witten-Herdecke, Dr.-Friedrich-Steiner-Str. 5, 45711 Datteln, Germany \\ 2. Dept. of Neurology, Technical University of Dresden, Fetscherstraße 74, 01307 Dresden, Germany
}

Correspondence to: Dr. Petra Niklowitz, Vestische Kinderklinik Datteln, University Witten-Herdecke, Dr.-Friedrich-Steiner-Str. 5, D-45711 Datteln, 0049(0)2363/975296 (Tel), 0049(0)2363/64211 (Fax), pf-niklowitz@web.de (E-mail)

Received: 2007.03.21; Accepted: 2007.04.03; Published: 2007.04.05

Coenzyme Q10 (CoQ10) concentration in blood cells was analyzed by HPLC and compared to plasma concentration before, during, and after CoQ10 ( $3 \mathrm{mg} / \mathrm{kg} /$ day) supplementation to human probands. Lymphocyte DNA 8-hydroxydeoxy-guanosine (8-OHdG), a marker of oxidative stress, was analyzed by Comet assay.

Subjects supplemented with CoQ10 showed a distinct response in plasma concentrations after 14 and 28 days. Plasma levels returned to baseline values 12 weeks after treatment stopped. The plasma concentration increase did not affect erythrocyte levels. However, after CoQ10 supplementation, the platelet level increased; after supplementation stopped, the platelet level showed a delayed decrease. A positive correlation was shown between the plasma CoQ10 level and platelet and white blood cell CoQ10 levels. During CoQ10 supplementation, delayed formation of 8-OHdG in lymphocyte DNA was observed; this effect was long-lasting and could be observed even 12 weeks after supplementation stopped. Intracellular enrichment may support anti-oxidative defense mechanisms.

Key words: Coenzyme Q10, plasma, blood cells, Comet assay, oxidative damage

\section{Introduction}

Coenzyme Q10 (CoQ10) is a fat-soluble, vitamin-like, ubiquitous compound that functions as an electron carrier in the mitochondrial respiratory chain, as well as serving as an important intracellular antioxidant. CoQ10 protects phospholipids and mitochondrial membrane proteins from peroxidation and protects DNA against the oxidative damage that accompanies lipid peroxidation [1,2,3]. Clinical interest in CoQ10 analysis and its therapeutic effects is growing. Several clinical trials and case series have provided evidence supporting the use of CoQ10 in the prevention and treatment of various disorders $[4,5,6$, 7]. However, in contrast to other lipophilic antioxidants, endogenous synthesis, as well as food intake, contributes to CoQ10 levels [8]. Since tissue levels of CoQ10 may depend mainly on de novo synthesis [9], it is uncertain whether an extracellular supply of CoQ10 via the circulation could influence intracellular targets or exert a protective effect against oxidative DNA damage.

To allow for routine clinical investigation of intracellular CoQ10 concentrations, the authors focused on blood cells that could be easily isolated from small blood volumes. The present study was designed to elucidate the acute and long-term effects of in vivo CoQ10 enrichment in the plasma, to shed light on the incorporation of the antioxidant into blood cells, and to determine its effect on DNA damage in human lym- phocytes.

\section{Materials and Methods}

\section{Subjects and sample collection}

Ten female subjects (hospital staff members without any known diseases; average age 39 years; age range: $30-47$ years) were given nanodispersed CoQ10 (Sanomit ${ }^{\circledR}$ Q10, Monopreparation, MSE, Bad Homburg, Germany) in a dose of $3 \mathrm{mg} / \mathrm{kg}$ body weight, which was taken in the morning and evening for a total of 28 days. From each subject, $2 \mathrm{ml}$ venous EDTA blood were collected to analyze CoQ10 levels in erythrocytes and platelets, another $2 \mathrm{ml}$ of venous blood were collected to evaluate DNA strand breaks in lymphocytes using the Comet assay, and $1 \mathrm{ml}$ of venous heparinized blood was collected for analysis of plasma CoQ10 levels. The first set of samples was taken following an overnight fast, one hour before the first CoQ10 supplementation was taken. A second set of blood samples was taken after 14 days of supplementation, and a third set was taken after 28 days of supplementation in the morning following the last CoQ10 dose, which was taken the prior evening. A fourth set of blood samples was taken 12 weeks after the last dose had been taken (day 112).

In order to obtain more information about the effect of CoQ10 supplementation on white blood cell concentrations, 10 healthy subjects ( 3 males, 7 females; average age: 40 years; age range: $32-47$ years) received CoQ10 as described above for a total of 14 days. From 
each of them, $2 \mathrm{ml}$ venous EDTA blood was collected to analyze CoQ10 levels in platelets and white blood cells, and $1 \mathrm{ml}$ venous heparinized blood was collected for analysis of plasma concentrations. The first set of samples was taken following an overnight fast in the morning, one hour before the first CoQ10 dose. A second set of blood samples was taken after 14 days of supplementation in the morning following the last CoQ10 dose, which was taken the prior evening.

The study was approved by the Human Ethics Committee of the Medical Faculty of Witten-Herdecke University.

\section{Sample preparation and analysis}

When blood is collected into tubes with EDTA, the redox status of CoQ10 shifts in favour of the oxidized part during sample preparation. Therefore, to simultaneously measure the oxidized and reduced form of CoQ10 in the plasma, heparinized blood was collected; $100 \mu \mathrm{l}$ aliquots of plasma were stored at $-84^{\circ} \mathrm{C}$ until analysis of CoQ10 by HPLC [10]. Ten $\mu \mathrm{l}$ samples were stored at $-84^{\circ} \mathrm{C}$ until cholesterol level analysis was performed (CHOD-PAP-method, Human, Wiesbaden, Germany).

To analyze CoQ10 levels in blood cells, $2 \mathrm{ml}$ of venous EDTA blood was carefully placed above $2 \mathrm{ml}$ Ficoll separating solution (Ficoll, Biochrom KG, Berlin, Germany). After centrifugation (1000 g, $12 \mathrm{~min}$, braked softly), the red blood cell layer at the bottom of the tube was removed by aspiration and washed three times with $0.9 \%$ sodium chloride (centrifugation at $2500 \mathrm{~g}, 10 \mathrm{~min}$.). The final erythrocyte suspension was adjusted to a hematocrit of about $50 \% ; 230 \mu$ of the suspension were used to determine the number of cells present (Beckman Coulter, Gen.S, Krefeld, Germany). The number of white blood cells and platelets within the cell preparation was shown to be negligible. $100 \mu \mathrm{l}$ aliquots of the erythrocyte suspension were stored at $-84^{\circ} \mathrm{C}$, and the CoQ10 levels were determined within one week using HPLC as previously described [11].

The platelets and white blood cells in the intermediate layer of the Ficoll gradient were removed by aspiration and washed in $4 \mathrm{ml}$ PBS (Biochrom KG, Berlin, Germany). Centrifugation at $250 \mathrm{~g}$ for $12 \mathrm{~min}-$ utes separated the platelets (in the supernatant) from the white blood cells (in the pellet). The supernatant was transferred into a separate tube and then centrifuged at $2200 \mathrm{~g}$ for 12 minutes. The pellet was re-dissolved in $0.9 \%$ sodium chloride; $230 \mu \mathrm{l}$ of this suspension were used to determine the number of cells present. The number of remaining red and white blood cells within the cell preparation was found to be negligible. One $100 \mu \mathrm{l}$ aliquot was stored at $-84^{\circ} \mathrm{C}$ until analysis of CoQ10 levels using HPLC [12].

The white blood cell fraction (in the pellet after the first centrifugation step) was re-dissolved in $500 \mu \mathrm{l}$ $0.9 \%$ sodium chloride; $230 \mu \mathrm{l}$ of this suspension were used to determine the number of cells present. The number of red blood cells within the cell preparation was shown to be negligible; however, the white blood cell fractions were always contaminated by platelets, and this contamination could not be eliminated by further washing steps. Therefore, the platelet-portion of the CoQ10 level within the white blood cell fraction (average 27\%) was calculated and then subtracted. Two $100 \mu \mathrm{l}$ aliquots of the suspension were stored at $-84^{\circ} \mathrm{C}$ until analysis of the CoQ10 level by the double-determination method.

The CoQ10 level in blood cells was measured using HPLC with electrochemical detection and internal standardization according to a previously published method [11, 12]. As an internal standard, 23 pmol of ubihydrochinone-9 plus 3 pmol ubiquinone- 9 (Sigma, Deisenhofen, Germany) in $50 \mu$ l ethanol were added to a $100 \mu \mathrm{l}$ platelet and white blood cell suspension, and 33 pmol ubiquinone-9 in $50 \mu \mathrm{l}$ ethanol were added to a $100 \mu$ l erythrocyte suspension. The cells were disintegrated by adding cold methanol, extracted with hexane, and evaporated under a stream of argon. The dry residue was re-dissolved in $40 \mu \mathrm{l}$ ethanol and injected into the HPLC system.

To detect 8-OHdG (8-hydroxydeoxy-guanosine), a marker of oxidized DNA, so as to quantify oxidative damage present in the lymphocytes, single cell gel electrophoresis (Comet assay) was used, adapted from Singh and co-workers [13] and Collins [14]. $100 \mu \mathrm{l}$ of fresh isolated EDTA-blood samples were mixed with $100 \mu \mathrm{l}$ of cell culture freezing medium (GIBCO) and stored at $-80^{\circ} \mathrm{C}$. To analyze 8 -OHdG, $3 \mu \mathrm{l}$ aliquots were mixed with warm, low melting point agarose and plated on agarose-coated glass slides, which were then topped with cover slides. After congealing at $+4^{\circ} \mathrm{C}$ the plated glass slides were incubated in the dark for $1 \mathrm{~h}$ in lysis buffer $(2.5 \mathrm{M} \mathrm{NaCl}, 01 \mathrm{M}$ EDTA, $10 \mathrm{mM}$ Tris, $1 \%$ Triton X-100, $\mathrm{pH}$ 10.0). After washing in reaction buffer $(40 \mathrm{mM}$ Hepes $\mathrm{pH}$ 8.0, $0.1 \mathrm{M} \mathrm{KCl}, 0.5 . \mathrm{mM}$ EDTA, $0.2 \mathrm{mg} / \mathrm{ml} \mathrm{BSA}$ ), the plated glass slides were incubated at $37^{\circ} \mathrm{C}$ in the dark for $30 \mathrm{~min}$ with formamidopyrimidin DNA glycosylase and then for $25 \mathrm{~min}$ in TBE buffer. Following electrophoresis $(25 \mathrm{~V}, 300 \mathrm{~mA}$, $25 \mathrm{~min}$ ) the plated glass slides were washed 3 times for 5 minutes in $70 \%$ ethanol and silver-stained (Silver Staining Kit, TREVIGEN). The analysis of resulting tail moments of the DNA comets was done microscopically by rating 100 cells per sample, as per Singh and co-workers [13].

\section{Statistical methods}

Data are expressed as mean \pm SDM. Statistical analysis was performed using ANOVA (LSD method); correlations were analyzed using Spearman rank correlation.

\section{Results}

The analysis of CoQ10 levels after oral supplementation in healthy female subjects revealed a significant response after 14 days of supplementation [Table 1]. Continuing CoQ10 supplementation for another 14 days led to a slight, though not significant, further increase. Twelve weeks after the last CoQ10 dose, plasma CoQ10 concentration had returned to baseline values. The plasma CoQ10 concentration depends on the concentration of lipoproteins that act as carriers of lipophilic molecules, such as CoQ10. How- 
ever, a significant increase in the plasma CoQ10 concentration was also found after adjustment for lipid levels. Following an increase in the plasma CoQ10 concentration, the oxidized part of the total concentration decreased. While oral supplementation did not affect erythrocyte concentrations, CoQ10 supplementation significantly increased platelet CoQ10 levels after 14 days of supplementation, and to a further (though not statistically significant) increase after 28 days of supplementation. Twelve weeks after supplementation ended, platelet CoQ10 concentration again decreased, but not to the same extent as the plasma CoQ10 concentration. When all of the platelet/plasma pairs were correlated independently from the time of measurement, a positive correlation between the plasma concentration and the platelet concentration of CoQ10 (Spearman rank correlation co-efficient, $\mathrm{r}=0.7$, $\mathrm{p}<0.00001 ; \mathrm{n}=40$ ) was found. In platelets, the oxidized part of CoQ10 of the total concentration decreased with increasing total concentrations. The Comet assay did not identify a decrease in the 8-OHdG content in lymphocyte DNA until 28 days of CoQ10 supplementation; however, a decrease in the 8-OHdG content in lymphocyte DNA could be observed even 12 weeks after the termination of supplementation.

In the mixed-gender treatment group, oral CoQ10 supplementation led to a significant increase in plasma and platelet CoQ10 levels after 14 days of supplementation. As well, it was found that increased plasma CoQ10 levels were linked to CoQ10 incorporation into white blood cells [Figure1]. When all blood cell/plasma pairs were correlated independently from the time of measurement, a positive correlation be- tween plasma CoQ10 concentration and platelet CoQ10 content (Spearman rank correlation co-efficient, $\mathrm{p}<0.001, \mathrm{n}=20$ ) as well as plasma and white blood cell CoQ10 concentration (Spearman rank correlation co-efficient, $\mathrm{p}<0.05, \mathrm{n}=20$ ) was found [Figure 2].

Table 1: Coenzyme Q10 in healthy female subjects before (day 0), during supplementation (day 14, day 28) with Sanomit Q10 (3 mg/kg/day), and 12 weeks after the last oral dose (day 112). Data are expressed as mean \pm SDM $(n=10)$. Statistical analysis was performed by ANOVA (LSD method; * $<<0.05$ ).

\begin{tabular}{|c|c|c|c|c|}
\hline $\begin{array}{l}\text { CoQ10 supple- } \\
\text { mentation }\end{array}$ & Day 0 & Day 14 & Day 28 & Day 112 \\
\hline $\begin{array}{l}\text { Plasma CoQ10 } \\
(\mu \mathrm{mol} / \mathrm{L})\end{array}$ & $1.02 \pm 0.30$ & $3.93 \pm 1.29^{*}$ & $4.11 \pm 1.08^{*}$ & $1.12 \pm 0.30$ \\
\hline $\begin{array}{l}\text { Plasma CoQ10 } \\
\text { lipid-related } \\
(\mu \mathrm{mol} \mathrm{Q10/mol} \\
\text { chol })\end{array}$ & $243 \pm 68$ & $941 \pm 215^{*}$ & $865 \pm 168^{*}$ & $224 \pm 56$ \\
\hline $\begin{array}{l}\text { Plasma CoQ10 } \\
\text { redox-status } \\
\text { (\%Q10 oxidized in } \\
\text { Q10 } \\
\text { total })\end{array}$ & $10.2 \pm 4.1$ & $5.8 \pm 1.6^{*}$ & $6.1 \pm 1.9^{*}$ & $7.5 \pm 0.9^{*}$ \\
\hline $\begin{array}{c}\text { Erythrocyte } \\
\text { CoQ10 } \\
\text { (pmol/cells } \\
\text { x10 })\end{array}$ & $32.8 \pm 8.8$ & $33.3 \pm 10.4$ & $34.8 \pm 12.0$ & $34.0 \pm 12.2$ \\
\hline $\begin{array}{c}\text { Platelet CoQ10 } \\
(\mathrm{pmol} / \mathrm{cells} \\
\left.\mathrm{x} 10^{9}\right)\end{array}$ & $190 \pm 57$ & $374 \pm 224^{*}$ & $441 \pm 156^{*}$ & $256 \pm 57$ \\
\hline $\begin{array}{l}\text { Platelet CoQ10 } \\
\text { redox-status } \\
\text { (\%Q10 oxidized in } \\
\text { Q10 } \\
\text { total })\end{array}$ & $19.8 \pm 6.6$ & $14.0 \pm 4.6^{*}$ & $14.9 \pm 3.8^{*}$ & $17.8 \pm 5.4$ \\
\hline $\begin{array}{l}\text { Comet-Assay } \\
\text { (tail moment) }\end{array}$ & $1.47 \pm 0.23$ & $1.48 \pm 0.13$ & $1.29 \pm 0.13^{*}$ & $1.24 \pm 0.17^{*}$ \\
\hline
\end{tabular}
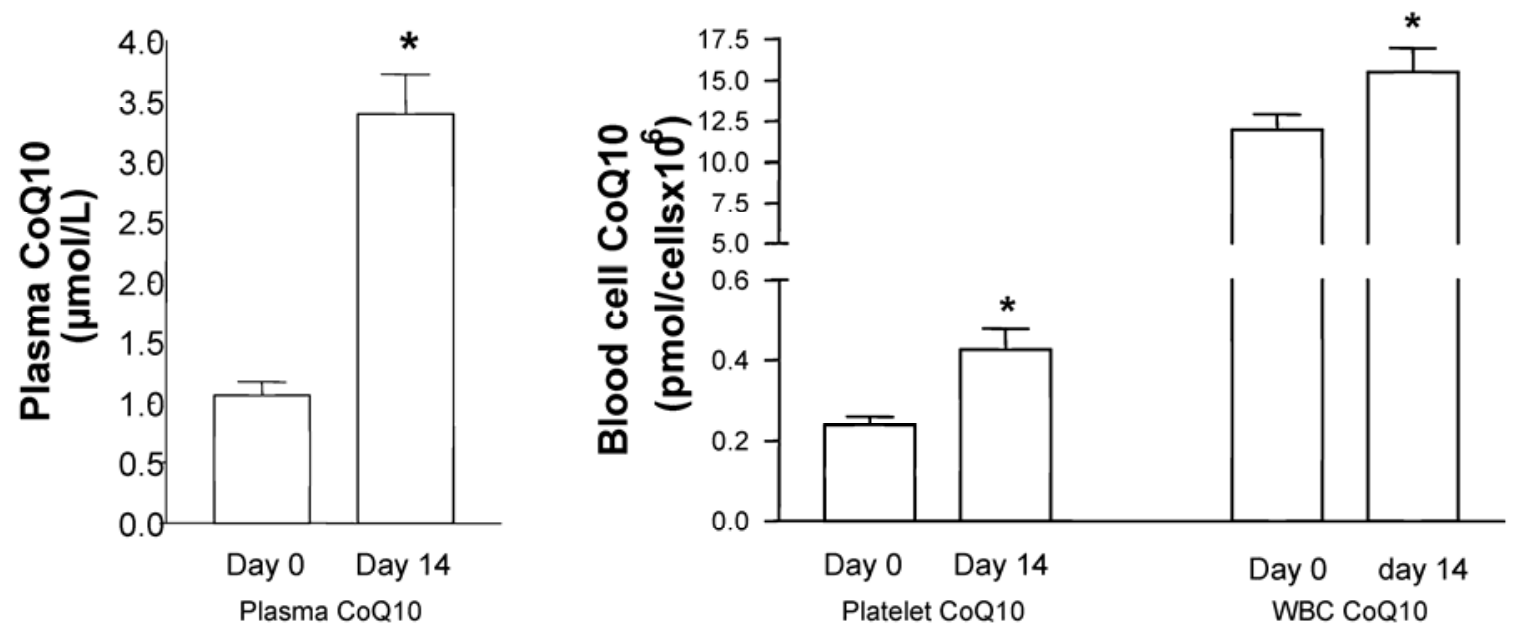

Fig. 1: Coenzyme Q10 levels in plasma, platelets, and white blood cells (WBC) of healthy subjects before and after 14 days of supplementation with Sanomit ${ }^{\circledR}$ Q10 (3 mg/kg/day). Data are expressed as mean \pm SDM $(n=10)$. Statistical analysis was performed by ANOVA (LSD method, $\mathrm{p}<0.05$ ). 


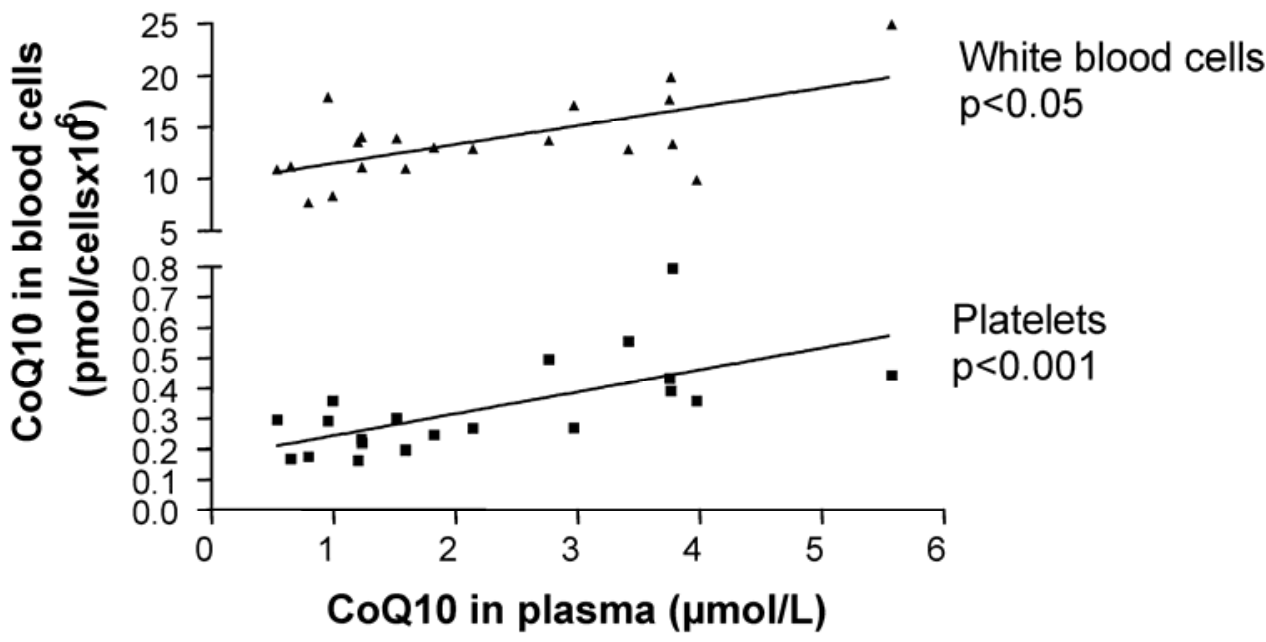

Fig. 2: Total Coenzyme Q10 concentrations in platelets and white blood cells correlated to total plasma CoQ10 concentration (Spearman rank correlation).

\section{Discussion}

The bioenergetic property of coenzyme Q10 combined with its function as an important lipophilic antioxidant makes CoQ10 unique. The CoQ10 content of organs and membranes depends on their functional requirements and exhibits great variations not only in different tissues but also within the same organ and among individual cell membranes [15]. Decreased blood and tissue CoQ10 concentrations have been reported in various disease processes $[5,8]$. The results of several clinical trials and case series support the use of CoQ10 in the prevention and treatment of various disorders, such as congestive heart failure [16, 17], Parkinson's disease [18, 19], and breast cancer [20, 21]. However, it is uncertain whether a CoQ10 deficiency is the cause or the effect of disease. Since CoQ10 comes from food intake and endogenous synthesis, the question has arisen whether tissue levels can be influenced by exogenous supply or are regulated predominantly by endogenous synthesis. The routine clinical assessment of CoQ10 status is generally based on plasma measurements. As plasma concentrations may not adequately represent cellular concentrations, other suitable targets that can act as surrogates for tissue CoQ10 levels have to be found. The establishment of routine clinical assessment of intracellular CoQ10 levels requires easy access to small amounts of material. Blood cells fulfill these requirements, and they allow intracellular CoQ10 levels to be compared to plasma levels. Another reason to choose blood cells as targets for determining intracellular CoQ10 levels may be the different characteristics of the various blood cells; mature erythrocytes and platelets have no nuclei, while platelets have mitochondria, and white blood cells have nuclei. Differences in incorporation of CoQ10 into these cells may suggest intracellular targets.

The present study compared CoQ10 levels in various blood cells and in their external environment in healthy adult subjects before, during, and after oral CoQ10 supplementation. The baseline CoQ10 levels in blood cells were in agreement with previously reported data [22]. The effect of CoQ10 supplementation on DNA strand breakdown in lymphocytes was analyzed. In this part of the study, only female subjects were included because our Comet assay may be more effective in females (unpublished data).

In agreement with previous findings [11, 12] in healthy subjects, an excessive level of nanodispersed CoQ10 can be achieved by the oral administration of high doses of CoQ10 (3 mg/ kg/day); subjects given CoQ10 had distinct but individually different increases in plasma CoQ10 concentrations. As expected, 12 weeks after supplementation was stopped, plasma concentrations returned to baseline values. The plasma half-life of CoQ10 is about 33 hours [8]. In the circulation, CoQ10 is carried by lipoproteins and is primarily bound to LDL. A significant increase in plasma CoQ10 concentration following oral supplementation was also found when the plasma concentrations were normalized to the lipid content; this shows that lipoproteins posses a residual binding capacity for orally administered CoQ10. In agreement with previous reports $[11,12]$, the present study found a decrease in the oxidized portion of CoQ10 at increasing total plasma concentrations.

As has been previously demonstrated [11, 12], high plasma CoQ10 levels did not affect red blood cell CoQ10 concentrations in healthy adults. Inter-individual differences in erythrocyte CoQ10 content were independent of the cell volume and were found to be stable. A low erythrocyte CoQ10 level has been reported in schizophrenic patients [23]. However, in patients suffering from sickle cell anemia - a genetic anemia characterized by an overall accelerated production of reactive oxygen species - the CoQ10 erythrocyte concentrations were found to be dramatically elevated in the presence of normal or low plasma concentrations [11]. This finding suggests the possibility that there are discrepancies between extracellular and intracellular CoQ10 concentrations.

Platelet CoQ10 concentrations increased with increasing plasma concentrations during supplementa- 
tion. This increase was accompanied by a shift in the redox status favoring the reduced part. However, there was a delay in the decrease in the platelet CoQ10 concentration after supplementation was stopped.

An excessive supply of CoQ10 may not influence the outer cell membrane compartments of erythrocytes but may influence intracellular compartments. In the present study, the total plasma CoQ10 concentration was correlated with the platelet and white blood cell CoQ10 concentrations. Since no correlation has been demonstrated between plasma and platelet CoQ10 levels in healthy subjects [12], an interaction between blood cell CoQ10 levels and plasma CoQ10 levels may be only expected in deficient situations or during excessive supply.

Since blood platelets contain mitochondria, they are a suitable cellular target for assessing intracellular CoQ10 concentrations, especially in patients with neurodegenerative or mitochondrial diseases. CoQ10, due to its role in mitochondrial electron transport and in antioxidant defense, has been proposed as a protective agent for patients with Parkinson's disease [18, 19], in which both mitochondrial dysfunction and neuronal damage due to oxidative free radicals occur. However, clinical recommendations with respect to the use of CoQ10 in mitochondrial diseases are inconsistent [24, 25]. Thus, it is necessary to prove that orally supplemented CoQ10 is incorporated into intracellular targets.

A deficiency in plasma CoQ10 levels has been found in various cancer diseases; the potential therapeutic benefit of CoQ10 supplementation has been discussed [26, 27]. However, the little that is known about tissue CoQ10 concentrations in cancer patients is contradictory $[28,29]$. While serum CoQ10 concentrations of lung carcinoma patients have been reported to be decreased, platelet CoQ10 concentrations appear to be unaffected [30]. Decreased plasma CoQ10 concentrations in cancer patients may be due to an increased consumption of this antioxidant by free radicals or may be caused by an increased extraction of CoQ10 from the blood due to increased tumor cell demand.

The extracellular supply of CoQ10 through the circulation influences CoQ10 levels in blood cells. However, the mechanism of intracellular incorporation is not completely understood. The intracellular incorporation of lipophilic antioxidants may be linked to the cellular incorporation of lipoproteins [31, 32]. The different pharmacokinetic characteristics of CoQ10 in plasma and in blood cells suggests that intracellular transport is not a simple diffusion mechanism.

The experiments of Tomasetti and coworkers [33] have shown that in vitro CoQ10 supplementation enhances DNA resistance towards $\mathrm{H}_{2} \mathrm{O}_{2}$-induced oxidative DNA damage in human lymphocytes. In the present study, oral CoQ10 supplementation supported in vivo intracellular antioxidative defense mechanisms, as inhibition of DNA strand breakdown in lymphocytes was demonstrated. Interestingly, it may take several weeks of supplementation to achieve this effect. On the other hand, once achieved, the effect may be a long-term, protective effect that can last for several weeks after supplementation is stopped. Since intracellular enrichment with CoQ10 may decrease oxidative damage of lymphocyte DNA in healthy adults, this protective effect of CoQ10 may be even more marked in pathophysiological conditions present in patients suffering from pro-oxidative diseases.

In conclusion, the oral administration of CoQ10 in sufficient doses leads to the incorporation of CoQ10 into platelets and white blood cells. Thus, blood cells may provide suitable targets for assessing intracellular CoQ10 concentrations. Intracellular enrichment may support cellular antioxidative defense mechanisms.

\section{Acknowledgements}

This work was supported by the patients self-help group "Elterninitiative Tumorkranker Kinder e.V. der Vestischen Kinderklinik Datteln", Germany, and by the "Peter and Ruth Wirts-Foundation", Switzerland.

\section{Conflict of Interests}

The authors have declared that no conflict of interest exists.

\section{References}

1. Crane FL, Sum EE. The essential functions of Coenzyme Q. Clin Invest. 1993; 71:55-59.

2. Forsmark AP, Ernster L. Evidence for a protective effect of endogenous ubiquinol against oxidative damage to mitochondrial protein and DNA during lipid peroxidation. Mol Aspects Med. 1994; 15:73-81.

3. Ernster L, Dallner G. Biochemical, physiological and medical aspects of ubiquinone function. Biochim Biophys Acta. 1995; 1271:195-204.

4. Fuke C, Krikorian SA, Couris RR. Coenzyme Q10: a review of essential functions and clinical trials. US Pharmacist. $2000 ;: 28-41$.

5. Hargreaves IP. Ubiquinone: cholesterol's reclusive cousin. Ann Clin Biochm. 2003; 40:207-218.

6. Rosenfeldt F, Hilton D, Pepe S, Krum H. Systematic review of effect of coenzyme Q10 in physical exercise, hypertension and heart failure. Biofactors. 2003; 18:91-100.

7. Beal MF. Mitochondrial dysfunction and oxidative damage in Alzheimer's and Parkinson's diseases and coenzyme Q10 as a potential treatment. J Bioenerg Biomembr. 2004; 36:381-386.

8. Overvad K, Diamant B, Holm L, Holmer G, Mortensen SA, Stender S. Coenzyme Q10 in health and disease. Europ J Clin Nutr. 1999; 53:764-770.

9. Zang Y, Aberg F, Appelkvist E-L, Dallner G, Ernster L. Uptake of dietary coenzyme $Q$ supplement is limited in rats. J Nutr. 1995; 154:446-453.

10. Menke T, Niklowitz P, Adam S, Weber M, Schlüter B, Andler W. Simultaneous detection of ubiquinol-10, ubiquinone-10, and tocopherols in human plasma microsamples and macrosamples as a marker of oxidative damage in neonates and infants. Anal Biochem. 2000; 282:209-217.

11. Niklowitz P, Menke T, Wiesel T, Mayatepek E, Zschocke J, Okun JG, Andler W. Coenzyme Q10 in plasma and erythrocytes: comparison of antioxidant levels in healthy probands after oral supplementation and in patients suffering from sickle cell anemia. Clin Chim Acta. 2002; 326:155-161.

12. Niklowitz P, Menke T, Andler W, Okun JG. Simultaneous analysis of coenzyme Q10 in plasma, erythrocytes and platelets: comparison of the antioxidant level in blood cells and their en- 
vironment in healthy children and after oral supplementation in adults. Clin Chim Acta. 2004; 342:219-226.

13. Singh NP, McCoy MT, Tice RR, Schneider EL. A single technique for quantification of low levels of DNA damage in individual cells. Exp Cell Res. 1988; 175:184-191.

14. Collins AR. The comet assay for DNA damage and repair. Mol Biotechnol. 2004; 26:249-261.

15. Dallner G, Sindelar PJ. Regulation of ubiquinone metabolism. Free Rad Biol Med. 2000; 29:285-294.

16. Morisco C, Trimarco B, Condonelli M. Effect of coenzyme Q10 therapy in patients with congestive heart failure: a long-term, multicenter randomised study. Clin Investig. 1993; 71:134-136.

17. Hofman-Bang C, Rehnquist N, Swedberg K, Wiklund I, Astrom $\mathrm{H}$. Coenzyme Q10 as an adjunctive in the treatment of chronic congestive heart failure. The Q10 study group. J Card Fail. 1995;1: 101-107.

18. Shults CW, Haas RH, Beal MF. A possible role of coenzyme Q10 in the etiology and treatment of Parkinson's disease. BioFactors. 1999; 9:267-272.

19. Mueller T, Buettner T, Gholipour AF, Kuhn W. Coenzyme Q10 supplementation provides mild symptomatic benefit in patients with Parkinson`s disease. Neurosci Lett. 2003; 341:201-204.

20. Lockwood K, Moesgaard S, Folkers K. Partial and complete regression of breast cancer in patients in relation to dosage of coenzyme Q10. Biochem Biophys Res Commun. 1994; 199:1504-1508.

21. Lockwood K, Moesgaard S, Yamamoto T, Folkers K. Progress on therapy of breast cancer with vitamin Q10 and the regression of metastases. Biochem Biophys Res Commun. 1995; 212:172-177.

22. Littarru GP, Lippa S, Oradei A, Fiorini RM, Mazzanti L. Metabolic and diagnostic implications of human blood CoQ10 levels. In: Folkers K, Littarru GP, Yamagami T, eds. Biomedical and clinical aspects of coenzyme Q, Elsevier Science Publishers; 1991: 167-178.

23. Imagawa M. Low erythrocyte coenzyme Q10 level in schizophrenic patients. Jpn J Psychiatry Neurol. 1989; 43:143-145.

24. Bresolin N, Doriguzzi C, Ponzetto C, Angelini C, Moroni I, Castelli E, et al. Ubidecarinone in the treatment of mitochondrial myopathies: a multi-center double-blind trial. J Neurol Sci. 1990; 100:70-78.

25. Matthews DR, Ford B, Dandurard RJ. Coenzyme Q10 with multiple vitamins is generally ineffective in treatment of mitochondrial diseases. Neurology. 1993; 43:884-890.

26. Folkers K, Osterborg A, Nylander M, Morita M, Mellstadt H. Activities of vitamin $Q(10)$ in animal models and a serious deficiency in patients with cancer. Biochem Biophys Res Commun. 1997; 234:296-299.

27. Jolliet P, Simon N, Barre J, Pons J-Y, Boulcef M, Paniel BJ, et al. Plasma coenzyme Q10 concentrations in breast cancer: prognosis and therapeutical consequences. Int Clin Pharmacol Ther. 1998; 36:506-509.

28. Chipperfield B. Ubiquinone concentrations in tumours and some normal tissue in man. Nature. 1966; 209:1207-1209.

29. Portakal O, Ozkaya O, Inal M, Bozan B, Kosan M, Sayek I. Coenzyme Q10 concentrations and antioxidant status in tissue of breast cancer patients. Clin Biochem. 2000; 33:279-284.

30. Shinkai T, Tominaga K, Shimabukuro Z, Shimizu E, Eguchi K, Saijo N, et al. Platelet aggregation and coenzyme Q10 content in platelets in cancer patients. Gan To Kagaku Ryoho. 1984; 11:87-96.

31. Thellmann CA, Shireman RB. In vitro uptake of a-tocopherol from low density lipoproteins by cultured human fibroblasts. J Nutr. 1985; 115:1673-1679.

32. Cohn W, Gross P, Grun H, Loechleiter, Muller PR, Zulauf M. Tocopherol transport and adsorption. Proc Nutr Soc. 1992; 51:179-188.

33. Tomasetti, Littarru GP, Stocker R, Alleva. Coenzyme Q10 en- richment decreases oxidative DNA damage in human lymphocytes. Free Radic Biol Med. 1999; 27:1027-1032. 